\title{
Solar Retinopathy Secondary to Solar Eclipse Gazing: A Case Report from Nepal
}

\section{Keshav Acharya $^{1 *}$ and Janak Poudel ${ }^{2}$}

${ }^{1}$ Consultant Optometrist, B. Optom, Metro Eye Care, Kathmandu, Nepal

${ }^{2}$ Consultant Optometrist, B. Optom, Medical Genetics and Genetic Counsellor, Kriti

Eye Care, Kathmandu, Nepal

*Corresponding Author: Keshav Acharya, Consultant Optometrist, B. Optom,

Metro Eye Care, Kathmandu, Nepal.

DOI: 10.31080/ASOP.2022.05.0464
Received: December 23, 2021

Published: February 09, 2022

(C) All rights are reserved by Keshav Acharya and Janak Poudel.

\section{Abstract}

Solar retinopathy is a photochemical damage to the retina, generally due to direct or indirect solar observation or during eclipse. We document the case of a solar retinopathy in a 19-year-old male who presented with the complaint of blurring of central vision in both eyes since a day after the solar eclipse dated 26th December 2019 (Annular Eclipse). He had a history of gazing solar eclipse through the reflecting plain mirror for about one minute.

During examination, his visual acuity was reduced to 6/12 bilaterally and the fundus examination revealed discrete yellow lesions at each maculae. Optical Coherence Tomography (OCT) shows RPE defects at both fovea, which shows the signs of improvement and only a few changes to normal after a certain month. The symptoms were reduced and patient had no complaints when he appeared to our clinic one month later. Thus, we should make everyone aware about using goggles/ eye protection during sun exposure to reduce the risk which is highly susceptible to retinal damage, which turned into probably the case for this patient.

Keywords: Visual Acuity (VA); Optical Coherence Tomography (OCT); Retinal Pigment Epithelium (RPE); Solar Retinopathy

\section{Introduction}

Solar retinopathy, additionally referred to as photo maculopathy, eclipse retinopathy and foveomacular retinitis, is retinal damage resulting from direct or indirect sun observation during a solar eclipse or on a normal day [1]. Light can damage the retinal tissue generally which are present at the fovea which results in reduced visual acuity and/or central or paracentral scotoma. Photochemical harm takes place for the duration of extended low irradiance exposure that lasts greater than 10 seconds.

Common presenting signs and symptoms consist of reduced VA, metamorphopsia, central or paracentral scotoma, after-image and dyschromatopsia. Onset of signs and symptoms is normally within 4 - $6 \mathrm{~h}$ of exposure. After exposure to sun, VA usually drops from normal to $6 / 60$, and after some months of exposure it may get improved to $6 / 6$ or $6 / 9[2]$.
Retinal impairment may be mild or severe. Young people are maximum prone to damage. Recovery of VA as well as fundus injury may take place after some months or even a year after the exposure, also improvement of visual acuity may be incomplete which results in permanent VA loss and central or paracentral scotomata [3-4].

\section{Case Report}

A 19 year old male complained about a sudden bilateral blurring in his central visual field since two days. He had a history of gazing solar eclipse through the reflecting plain mirror for about one minute. On examination the visual acuity of patient was $6 / 12$ both eyes. There was no any improvement of visual acuity through pinhole. Slit-lamp bio microscopy examination of fundus revealed the discrete yellow lesions at the fovea of both eyes. OCT report 
showed the RPE defects in both eyes (Figure $1 \mathrm{~A}$ and B). Conservative management was explained and was well advised for regular follow up to patient.

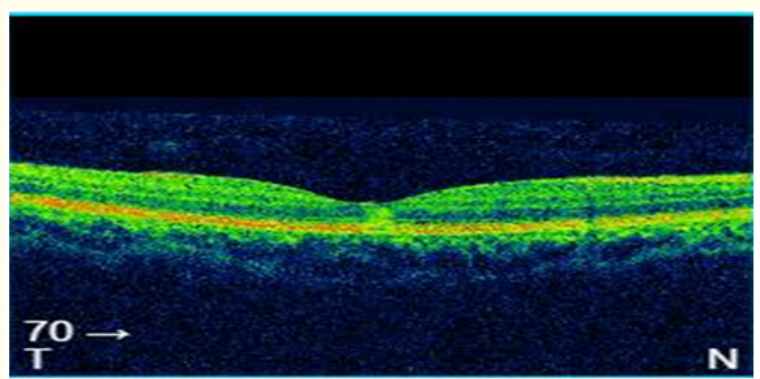

Figure 1A: Right Eye OCT picture taken at the first visit to the clinic showing RPE defects.

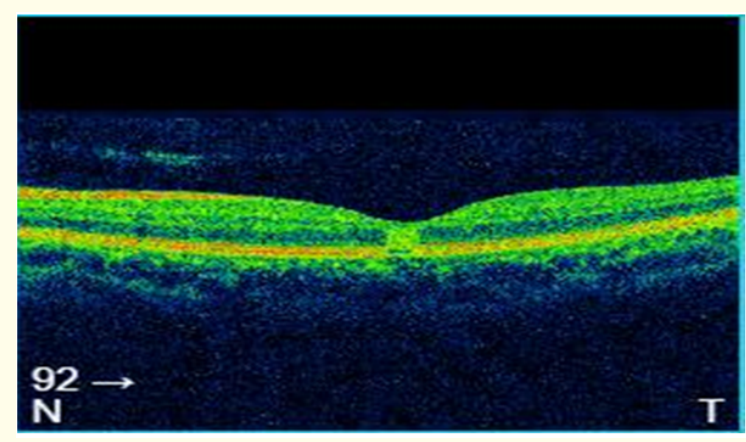

Figure 1B: Left Eye OCT picture taken at the first visit to the clinic showing RPE defects.

The discrete yellow lesion in the fovea is illustrated below in the fundus picture of both eyes (Figure $2 \mathrm{~A}$ and $\mathrm{B}$ ).

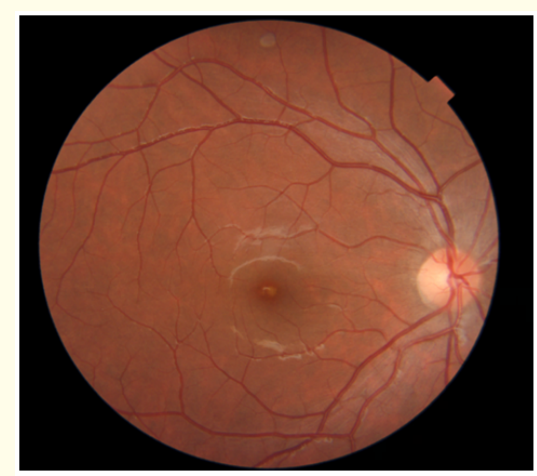

Figure 2A: Right Eye fundus photograph showing yellow discrete lesion over fovea.

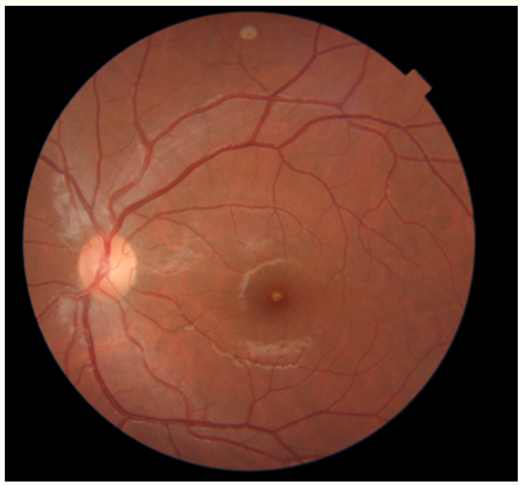

Figure 2B: Left Eye fundus photograph showing yellow discrete lesion over fovea.

The patient was called for the first follow up after one month and the Visual acuity, Colour vision and Contrast sensitivity were examined. The visual acuity of both of his eyes was $6 / 6$ in this visit. Similarly, the colour vision was normal as assessed with Ishiara Chart and Contrast sensitivity was 1.50 which was examined with Pelli Robinson Chart.

The Fundus examination revealed faint yellowish lesion in both of his fovea and OCT revealed very few RPE changes. The OCT of both the eyes are illustrated below (Figure $3 \mathrm{~A}$ and $\mathrm{B}$ ).

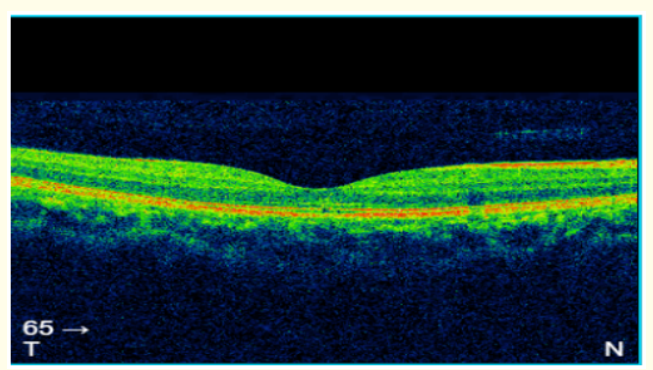

Figure 3A: Right Eye OCT picture taken One month post Solar Eclipse viewing.

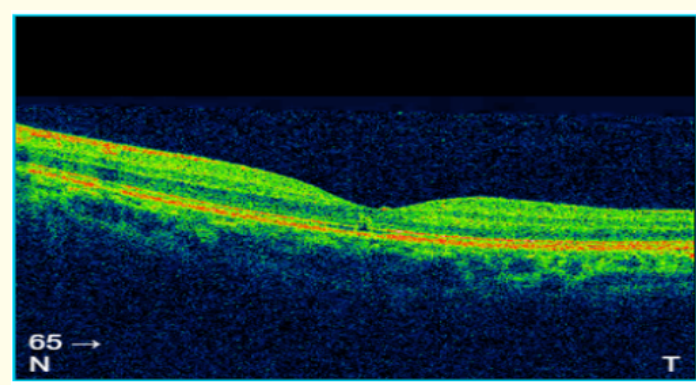

Figure 3B: Left Eye OCT picture taken One month post Solar Eclipse viewing. 


\section{Discussion}

After the exposure various situation like: intensity of radiation, duration of exposure, and light spectrum of the exposure; clearness of the ocular media; ocular pigmentation; body temperature; environmental situations, like highly reflective surroundings and atmospheric changes can affect the severity of the clinical and morphological presentation [5-6].

Mostly people come forward with signs like: reduced VA, metamorphopsia, central or paracentral scotoma, after-image and dyschromatopsia. Onset of symptoms is normally within $4-6 \mathrm{~h}$ of exposure [2]. Solar retinopathy is generally visible as bilateral, although unilateral and asymmetric manifestations had been described [3,7-10]. Fundus examinations in acute stages can show a small yellow spot on the fovea, encircled by faint gray granular pigmentation [8]. The yellowish discoloration will generally come to be faint with time, leaving a pathogonomic reddish spot [8].

Gass postulated that, solar retinopathy may be photochemical damage mediated by highly reactive free radicals $[6,8]$. Through light induced damage of the apical melanosomes of the RPE by the blue-light wavelengths. The dominant pathophysiological mechanism in our cases was thermal due to which the changes in outer retina were seen usually, and it may be possible that our patients had a more severe form of solar retinopathy, with the involvement of the whole foveal retina [11-15].

Reduced VA due to solar retinopathy is expected to improve till normal i.e. either $6 / 6$ or $6 / 9$ and only a few cases are expected to have a permanent visual loss. Till date there are no any particular treatment for solar retinopathy. Only as a prevention method for solar retinopathy we can make people awareness about the causes of it and educate them to use the appropriate protective measures while viewing the solar eclipse as well as to reduce the exposure time [16-30]. And still there is a religious norms in Nepal as well as in India, during solar eclipse parents request us not to go out during that interval of time. Although it might be a religious beliefs but it is beneficial for our eyes.

\section{Bibliography}

1. Kevin C. "Solar Retinopathy: Etiology, Diagnosis, and Treatment". Retinal Physician 10 (2013): 46-50.

2. Jain A., et al. "Solar Retinopathy: Comparison of OCT and Fluorescein Angiography". Retina 29 (2009): 1340-1345.
3. M Codenotti., et al. "OCT findings in patients with retinopathy after watching a solar eclipse". Ophthalmologica 216.6 (2002): 463-466.

4. Ham WT Jr., et al. "Histologic analysis of photochemical lesions produced in rhesus retina by short-wavelength light". Investigative Ophthalmology and Visual Science 17 (1978): 10291035.

5. Solar Retinopathy: A multimodal Analysis (case report)@ 2013 clavdia Brue et al. Hindawi (2013).

6. LA Yannuzzi., et al. "Solar retinopathy. A photobiologic and geophysical analysis". Retina 9.1 (1989): 28-43.

7. KCChen., et al. "High definition spectral domain optical coherence tomography findings in three patients with solar retinopathy and review of the literature". The Open Ophthalmology Journal 6 (2012): 29-35.

8. JDM Gass. "Photic maculopathy," in Stereoscopic Atlas of Macular Diseases, St. Louis, Mosby, Mo, USA, 4th edition (1997): 760-765.

9. J Comander., et al. "Highresolution optical coherence tomography findings in solar maculopathy and the differential diagnosis of outer retinalholes". American Journal of Ophthalmology 152 (2011): 413-419.

10. ML Katz and GE Eldred. "Retinal light damage reduces autofluorescent pigment deposition in the retinal pigment epithelium". Investigative Ophthalmology and Visual Science 30.1 (1989): 37-43.

11. Das T., et al. "Solar chorioretinal burn". American Journal of Ophthalmology 41 (1956): 1048-1053.

12. Agarwal LP and Malik SR. "Solar retinitis". British Journal of Ophthalmology 43 (1959): 366-370.

13. MacFaul PA. "Visual prognosis after solar retinopathy". British Journal of Ophthalmology 53 (1969): 534-541.

14. Ridgway AE. "Solar retinopathy". British Medical Journal 3 (1967): 212-214.

15. Anaclerio AM and Wicker HS. "Self-induced solar retinopathy by patients in a psychiatric hospital". American Journal of Ophthalmology 69 (1970): 731-736.

16. Glickman RD. "Ultraviolet phototoxicity to the retina". Eye Contact Lens 37 (2011): 196-205. 
17. White TJ., et al. "Chorioretinal temperature increases from solar observation". The Bulletin of Mathematical Biology 33 (1971): 1-17.

18. Boettner EA and Wolter JR. "Transmission of the ocular media". Investigative Ophthalmology and Visual Science 1 (1962): 776-783.

19. Dillon J., et al. "Transmission spectra of light to the mammalian retina". Photochemistry and Photobiology 71 (2000): 225-229.

20. Sliney DH. "How light reaches the eye and its components". International Journal of Toxicology 21 (2002): 501-509.

21. Davies S., et al. "Photocytotoxicity of lipofuscin in human retinal pigment epithelial cells". Free Radical Biology and Medicine 31 (2001): 256-265.

22. Jain A., et al. "Solar retinopathy comparison of optical coherence tomography (OCT) and fluorescein angiography (FA)". Retina 29 (2009): 1340-1345.

23. Chen JC and Lee LR. "Solar retinopathy and associated optical coherence tomography findings". Clinical and Experimental Optometry 87 (2004): 390-393.

24. Tso MO and La Piana FG. "The human fovea after sungazing". Transactions - American Academy of Ophthalmology and Otolaryngology 79 (1975): 788-795.

25. Hope-Ross MW., et al. "Ultrastructural findings in solar retinopathy”. Eye 7 (1993): 29-33.

26. Ham WT., et al. "Sensitivity of the retina to radiation damage as a function of wavelength". Photochemistry and Photobiology 29 (1979): 735-743.

27. Noell WK., et al. "Retinal damage by visible light". Investigative Ophthalmology 5 (1966): 450-473.

28. Wu J., et al. "Photochemical Damage of the Retina". Survey of Ophthalmology 51.5 (2006): 461-481.

29. Sperling HG and Johnson C. "Differential spectral photic damage to primate cones". Vision Research 20 (1980): 1117-1125.

30. Ham WT., et al. "Histologic analysis of photochemical lesions produced in rhesus retina by short-wavelength light". Investigative Ophthalmology and Visual Science 17 (1978): 10291035.

\section{Assets from publication with us}

- Prompt Acknowledgement after receiving the article

- Thorough Double blinded peer review

- Rapid Publication

- Issue of Publication Certificate

- High visibility of your Published work

Website: www.actascientific.com/

Submit Article: www.actascientific.com/submission.php

Email us: editor@actascientific.com

Contact us: +919182824667 